\title{
Cost of a roller skating rink to the local accident and emergency department
}

\author{
N. Nayeem FRCS ${ }^{1}$, S. E. Shires DRCOG ${ }^{2}$ and J. E. Porter FRCS ${ }^{3}$ \\ ${ }_{2}^{1}$ Milton Keynes General Hospital, Milton Keynes, UK \\ ${ }^{2}$ GP trainee, ${ }^{3}$ Southend Hospital, Southend, UK
}

\begin{abstract}
A 14 month retrospective study was undertaken to determine the cost implications of the opening of a roller skating rink to the local hospital accident and emergency department (A and E). A total of 398 patients attended following injury at the roller skating rink, of whom 384 were included in the study. The estimated cost of their injuries was determined by the hospital accounts department. The average cost per patient attending the $A$ and $E$ department following roller skating injury was about $£ 100$. The total cost to the $A$ and $E$ department of all injuries sustained at the rink over this period was $£ 38,412$. The cost implications of opening a roller skating rink for the $A$ and $E$ department are considerable. If proposals for self-budgeting are applied, $A$ and $E$ departments will have to seek additional funding if such leisure facilities are opened in their vicinity.
\end{abstract}

Keywords: Roller skating, accident and emergency department, hospital budget, leisure

\section{Introduction}

The leisure industry is booming. Sports and leisure facilities are becoming more adventurous and are likely to cause both major and minor injuries. Roller skating, ice skating and skate board facilities have appeared all over the country and are promoted as exciting, high speed leisure pursuits. The dangers of these sports to the inexperienced are often overlooked. There also seems to be little consideration of the implications of opening new leisure facilities on accident and emergency ( $\mathrm{A}$ and $\mathrm{E}$ ) departments ${ }^{1,2}$.

In June 1985 a roller skating rink was opened in Southend-on-Sea, Essex. The impact that this had on resources and the predicted financial implications of the rink was undertaken in a 14 month retrospective study of all injuries sustained at this roller skating rink.

Address for correspondence: N. Nayeem, Accident and Emergency Department, Milton Keynes General Hospital, Standing Way, Eaglestone, Milton Keynes MK6 5LD, UK

(C) 1990 Butterworth-Heinemann Ltd 0306-3674/90/040240-03

\section{Patients and methods}

A total of 4,088 new patients attended the A and E department with sports injuries in the 14 months of this study. Of those, $398(8.17 \%)$ sustained injuries while roller skating. Fourteen patients' notes have been lost, hence 384 patients have been studied. The mean age of the injured skater was 18 years (range 6 to 61 years). There were $236(61 \%)$ female and 148 (39\%) male subjects. The distribution of injuries is shown in Figure 1.

\section{Results}

Of the 384 patients, 185 sustained fractures and three dislocations to the various parts of the body (Table 1). The upper extremity was injured in 248 patients $(65 \%)$. The wrist was the most commonly injured area (176 patients). The lower extremity was injured

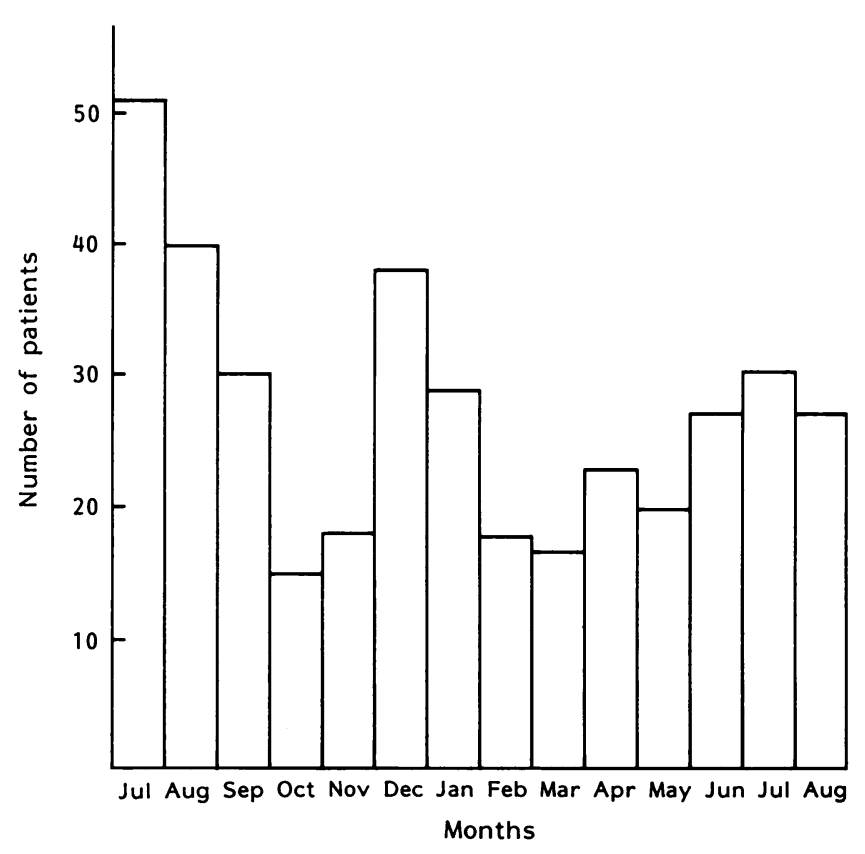

Figure 1. Number of patients seen in an accident and emergency department for injuries sustained during roller skating per month 
Table 1. Pattern of injuries to the extremities

\begin{tabular}{lrrrr}
\hline & Total & Fractures & Dislocations & $\begin{array}{r}\text { Soft } \\
\text { tissue } \\
\text { injury }\end{array}$ \\
& & & & \\
\hline Upper extremity & & & & \\
Hand & 32 & 10 & 2 & 20 \\
Wrist & 176 & 116 & 0 & 60 \\
Radius and ulna & 7 & 7 & 0 & 0 \\
Elbow & 30 & 23 & 0 & 7 \\
Humerus & 1 & 1 & 0 & 0 \\
Clavicle & 1 & 1 & 0 & 0 \\
Shoulder & 1 & 0 & 1 & 0 \\
Lower extremity & & & & \\
Foot & 4 & 0 & 0 & 4 \\
Ankle & 32 & 12 & 0 & 20 \\
Tibia & 23 & 10 & 0 & 13 \\
Knee & 24 & 0 & 0 & 24 \\
\hline
\end{tabular}

Table 2. Miscellaneous injuries

\begin{tabular}{|c|c|c|}
\hline $\begin{array}{l}\text { Head } \\
\text { Back } \\
\text { Chest }\end{array}$ & $\begin{array}{r}25 \\
19 \\
7\end{array}$ & $\begin{array}{l}\text { No skull fractures } \\
\text { One fractured vertebra } \\
\text { Three patients with one or more rib fractures } \\
\text { No haemo- or pneumothorax }\end{array}$ \\
\hline $\begin{array}{l}\text { Nose } \\
\text { Neck }\end{array}$ & $\begin{array}{l}1 \\
1\end{array}$ & $\begin{array}{l}\text { Nasal bone fracture } \\
\text { Neck sprain } \\
\text { No fracture or dislocation }\end{array}$ \\
\hline
\end{tabular}

Table 3. Patients admitted

\begin{tabular}{lcl}
\hline Injury & $\begin{array}{c}\text { No. of } \\
\text { patients }\end{array}$ & Reason for admission \\
\hline $\begin{array}{l}\text { Fracture of radius and } \\
\text { ulna }\end{array}$ & 11 & $\begin{array}{l}\text { Observation following } \\
\text { MUA }\end{array}$ \\
$\begin{array}{l}\text { Fracture of tibia and } \\
\text { fibula }\end{array}$ & 9 & $\begin{array}{l}\text { Three fractures internally } \\
\text { fixed. } \\
\text { Others for observation } \\
\text { following MUA } \\
\text { Both fractures internally } \\
\text { fixed }\end{array}$ \\
Ankle fractures & 2 & $\begin{array}{l}\text { For head injury } \\
\text { observations } \\
\text { Observation following } \\
\text { Head injury with loss of } \\
\text { consciousness }\end{array}$ \\
Supracondylar fracture & 1 & $\begin{array}{l}\text { MUA } \\
\text { Bed rest }\end{array}$ \\
Fracture of vertebrae & 1 &
\end{tabular}

in 83 patients $(21 \%)$ and 53 patients sustained injuries to various other parts of the body (Table 2). A total of 26 patients were admitted to the hospital (Table 3) and five fractures were internally fixed.

\section{Cost of roller skating injuries}

In assessing costs, certain assumptions had to be made. The figures below are only the direct costs and do not allow for administrative back-up, e.g. medical records or overheads:

Patients admitted (note 1)

$£ 3,606$

Attendance in $A$ and $E$

$£ 9,216$

Radiographs taken (note 2)
Follow-up clinics (note 3)

$£ 6,390$

Physiotherapy (note 4)

$£ 17,280$

Total cost

$£ 38,412$

Average cost per patient

$£ 100.03$

Note 1

These costs were calculated using:

Five patients for average stay of 5 days

plus 1 hour in theatre

21 patients admitted over-night only

$£ 1,176$

$£ 3,606$

\section{Note 2}

It is assumed that $55 \%$ of patients attending the A and $E$ department had a radiograph performed and all patients who sustained a fracture had at least two radiographs.

\section{Note 3}

The costs were calculated using the following assumptions:

All fractures and dislocations attended two followup clinic sessions

$30 \%$ of all soft tissue injuries attended a single follow-up session

\section{Note 4}

These were calculated on the basis of two sessions per week for 4 weeks for all fracture patients only.

Costs used for calculations

Cost per attendance in $\mathrm{A}$ and $\mathrm{E} \quad £ 24$

Cost per radiograph $£ 5$

Attendance at follow-up clinic $\quad £ 15$

In-patient cost per day $\quad £ 56$

Theatres - cost per hour $\quad £ 206$

Physiotherpay - cost per session $\quad £ 12$

\section{Note 5}

These figures have been worked out by the accounts department, Southend Health Authority, and are based on the cost of treating these injuries in 1985/86.

\section{Discussion}

The pattern of injuries in our study compared favourably with other reports in the literature ${ }^{3-6}$, and illustrates that, regardless of geography, the impact on acute services is fairly uniform and the cost implication considerable.

In estimating the cost considerations of these injuries, it was necessary for us to make certain assumptions which have been explained. However, our cost implications are formidable. The average cost to the $\mathrm{A}$ and $\mathrm{E}$ department of every patient attending following an injury at the roller skating rink averaged $£ 100$. Our costings are by necessity vague as the 


\section{Cost of roller skating: $\mathbf{N}$. Nayeem et al.}

National Health Service is not item-of-service orientated. If the Government is to enforce the recommendations of the White Paper, every A and E department will have to look carefully at the budget implications when a new leisure facility is opened.

Where should the additional funding come from? Will the hosptial or A and E department have to fund the resources internally, or will the local authorities provide extra funds to cover the cost of its improved leisure facilities? One of the more attractive proposals is that the leisure industry itself should contribute to the cost of its casualties.

Recent studies ${ }^{8}$ have advocated 'safe skating' by provision of separate supervised areas or special time for the beginners and unskilled skaters, use of crash helmets and wrist splints and better rink discipline. The leisure industry will be reluctant to follow these recommendations as this would lead to decreased profits. Therefore, we will continue to have a steady inflow of preventable accidents. However, if the leisure industry were expected to contribute to the cost of injuries sustained in their facilities, they would have a cost incentive to improve safety standards and thus would reduce the costs to the local $\mathrm{A}$ and $\mathrm{E}$ department.

Local planners should also be made aware of the medical implications associated with leisure facilities. Consultation with $\mathrm{A}$ and $\mathrm{E}$ departments before granting planning permission might allow additional safety recommendations to be built into the planning consent.

If hospitals and individual departments are to have budgets imposed on them, it is necessary for the
A and E departments to look carefully at existing and proposed leisure facilities in their catchment area and to ensure that additional funds are available to maintain the essential back-up for the leisure industries. In so doing it is hoped that the $\mathrm{A}$ and $\mathrm{E}$ department will develop closer co-operation with local planners and leisure industries to improve safety standards and promote safer leisure.

\section{Acknowledgements}

I am grateful to Mr J. N. Fletcher, Deputy Group Accountant (Acute), Southend Health Authority for his invaluable help in working out the cost of roller skating injuries. Also to Marilyn Watts for her typing.

\section{References}

1 Freeland, P. Implications of two newly opened ice rinks on an accident and emergency department $\mathrm{Br}$ Med J 1988, 296, 96

2 Prescott, M.V. The effect of opening an ice rink on the accident and emergency department of district general hospital Arch Emerg Med 1986, 3, 107-110

3 Sedlin, E.D., Zitner, D.T. and McGuinness G. Roller skating accidents and injuries Trauma 1984, 24(2), 136-139

4 Bunker, T.D. The 1982 epidemic - Roller skating injuries $\mathrm{Br} J$ Sports Med 1983, 17 (3), 205-208

5 Inkelis, S.H., Stroberg, A.J., Keller, E.L. and Christenson, P.D. Roller skating injuries in children Pediatr Emerg Care 1988, 4 (2), 127-132

6 Tse, P.Y.T., Shen, M.Y., Chan, K.M. and Leung, P.C. Roller skating - Is it a dangerous sport? Br J Sports Med 1983, 17 (3), 125-126

7 Secretaries of State for Health, Wales, Northern Ireland and Scotland. Working for patients London, HMSO, 1989, (Cmnd 555)

8 Horner, C. and McCabe, M.J. Ice skating and roller-disco injuries in Dublin Br J Sports Med 1984, 18 (3), 207-211 